\title{
DO RISO DEMONÍACO AO RISO RELIGIOSO NA IDADE MÉDIA
}

\section{FROM DEMONIACAL LAUGH TO RELIGIOUS LAUGH AT MIDDLE AGES}

\author{
Lucas Pires Ribeiro ${ }^{1}$
}

\begin{abstract}
RESUMO: O presente texto procura pensar o riso dentro da Idade Média, observando as maneiras que a Igreja Católica se valeu para relacionar com o fenômeno sociocultural. Diante das exigências políticas/religiosas, o riso foi associado ao Diabo, tendo representações voltadas para o processo de criação do mundo, passando pela construção da ideia de que Jesus nunca tivera rido em sua passagem pela terra. No entanto, mesmo com a austeridade e demonização por parte da Igreja, as pessoas continuaram rindo. Diante da constatação de que seria impossível retirar o riso da esfera social, a Igreja aos poucos foi suavizando as suas leituras, incorporando o riso em seu cotidiano, para defini-lo como objeto útil à sociedade a partir do século XII. Os referencias teóricos estão centrados em Alberti (1999), Le Goff (2000), Macedo (2000), Minois (2003) e outras importantes pesquisas que tateiam o riso no contexto medieval.
\end{abstract}

PALAVRAS-CHAVE: Idade Média; Igreja; Riso; Diabo; Jesus.

ABSTRACT: This paper aims to show the laughter within the Middle Ages, observing how the Catholic Church was used to relate itself to the sociocultural phenomenon. In the face of political / religious demands, laughter was associated with the Devil, with representations focused on the process of creation of the world, and the construction of the idea that Jesus had never laughed when he lived in the land. However, even with an austerity and demonization done by the Church, people continued to laugh. Faced with the confirmation that it would be impossible to remove laughter from the social sphere, the Church gradually softened its readings, incorporating laughter into its daily life, to define it as a useful thing for the society from the twelfth century. The theorical references are Alberti (1999), Le Goff (2000), Macedo (2000), Minois (2003) and other scientific papers that bring laughter in the medieval context.

KEY WORDS: Middle Ages; Church; Laughter; Devil; Jesus.

\section{Introdução}

Ao longo das últimas décadas, a temática em torno do riso tem suscitado inúmeras pesquisas dentro das denominadas ciências sociais. O riso compreendido como fenômeno

\footnotetext{
${ }^{1}$ Professor na Universidade Estadual de Goiás. lucas_nister@hotmail.com
} 
sociocultural, está presente em diferentes contextos de observação, passando por análises que inserem o fenômeno desde a Antiguidade, trazendo-o para abordagens que procuram compreender as relações das diferentes sociedades contemporâneas com o fenômeno em questão. De forma específica: "Para nos atermos a História, não se passa uma semana sem que um livro, um artigo, um programa de rádio, um colóquio ou uma conferência trate do riso nessa ou naquela época, nesse ou naquele meio" (MINOIS, 2003, p. 15). Se torna cada vez mais nítido entre os pesquisadores(as) da temática, que o riso entendido como objeto de estudo, possibilita a compreensão de inúmeros valores socioculturais de um determinado contexto.

A capacidade de compreensão estrutural por meio dos diferentes tipos de riso é atestada por Le Goff: “Ao observarmos como ele atua, seja em termos teóricos ou práticos, ele pode nos revelar as estruturas de uma sociedade e seus modos de funcionamento" (2000, p. 78). É diante dessa compreensão do riso como um fenômeno característico do ser humano, e como consequência, representativo do modus operandi de uma realidade social, que a presente pesquisa caminha. No entanto, pensa o riso de maneira delimitada, procurando compreender as formas de comportamento social, e de interpretações que o riso recebeu dentro da Idade Média, com destaque para as leituras da Igreja Católica.

Para isso, nos valemos de algumas possibilidades de intepretação sobre o tema, recorrendo ao caminho inevitável das ciências humanas, a saber, o campo das hipóteses, tão necessário para quem pesquisa, como salienta Le Goff: "É importante e necessário em uma pesquisa começar por arriscar hipóteses que ainda não possam ser fundamentadas por suficientes estudos, análises e reflexões, mas sem as quais, eu acredito, não faríamos progresso algum" (2000, p. 74). Assim, ter o objetivo de apresentar uma única teoria sobre o riso dentro da Idade Média, é algo impensável para esse artigo, porque não há uma receptividade única para com o riso dentro do contexto, mesmo se observado o comportamento da Igreja Católica, que transitou entre uma rigidez mais sistemática, para uma aceitação e incorporação do riso ao longo do transcorrer do tempo.

Diante dessa preliminar constatação de "metamorfose" do riso, o presente artigo traz uma problemática para ser tateada. A incorporação do riso pelo cristianismo, muito presente a partir do século XII, pode ser considerada uma vitória humana do riso em detrimento da seriedade sobrenatural do catolicismo? Enfim, para apresentar hipóteses acerca dessa questão, e de outros problemas que, inevitavelmente, irão se fazer presentes, recorremos a importantes pesquisas que se debruçam sobre a temática. 
Entre os autores(as) analisados está Le Goff (2000) e seu importante artigo sobre o riso na Idade Média, o clássico livro de Mikhail Bakthin (2013) sobre a cultura popular no medievo e no Renascimento, a pesquisa de Georges Minois (2003) sobre a história do riso e do escárnio, assim como Verena Alberti (1999) e sua análise teórica e historiográfica sobre o riso, e possivelmente, a pesquisa mais importante sobre a temática escrita em língua portuguesa, o livro de José Rivair Macedo (2000), no qual, o historiador pensa a relação do riso com os diferentes valores culturais dentro da Idade Média, com ênfase para o século XII e XIII. O riso na ótica desses pesquisadores foi um fenômeno indispensável para a sociedade europeia medieval, e no tempo presente, continua sendo um fenômeno histórico capaz de desnudar vários desdobramentos dessa sociedade.

\section{O Riso é uma Invenção do Diabo}

Quando se remete a uma pesquisa sobre a Idade Média, concomitantemente com as suas manifestações culturais, não resta dúvida, um dos principais pesquisadores, embora não se restrinja somente ao período medieval, é Mikhail Bakhtin e o seu clássico livro $A$ Cultura Popular na Idade Média e no Renascimento (2013). Bakhtin tece importantes considerações sobre a manifestação do riso, apresentando o fenômeno cultural como elemento representativo das camadas populares medievais, em detrimento das camadas oficiais, que em sua concepção, teriam se comportado durante a Idade Média por uma característica peculiar, a saber, a seriedade:

\footnotetext{
Como já mencionamos, o riso na Idade Média estava relegado para fora de todas as esferas oficiais da ideologia e de todas as formas oficiais, rigorosas, da vida e do comércio humano. O riso tinha sido expurgado do culto religioso, do cerimonial feudal e estatal, da etiqueta social e de todos os gêneros da ideologia elevada. O tom sério exclusivo caracteriza a cultura medieval oficial (2013, p. 63).
}

De um lado, seguindo a abordagem de Bakhtin estava a seriedade, compreendida pela oficialidade medieva como um mecanismo essencial para a conservação dos valores cristãos, e como consequência, para a transmissão da "verdade" bíblica, dos valores morais e de tudo que era considerado importante para a manutenção do funcionamento social/político: "Era a cultura oficial, a cultura da Igreja, a cultura dos homens cultos. Essa cultura foi caracterizada por Bakhtin como uma cultura do agelastoi, ou seja, das pessoas que nunca riam e que até odiavam o riso" (GUREVICH, 2000, p. 84). Nesse sentido, não rir para essa 
oficialidade cristã não era, necessariamente, uma escolha, mas, uma necessidade para quem desejava se aproximar dos desígnios divinos, se afastar dos homens "comuns" e manter intactas as estruturas da sociedade.

No entanto, "do outro lado", trabalhando com a antítese da seriedade, estavam as camadas populares, com destaque para os meios urbanos, que se caracterizavam por sua alegria, pelas festas, tendo o intuito de inverter os valores da sociedade. A alegria seria sinônimo da manifestação constante do riso, e teoricamente, rir era se colocar contrário à ordem social da Igreja Católica, que apregoava e valorizaria o indivíduo sério, por compreender na seriedade um passo importante de aproximação da salvação da alma e do corpo. O riso dos populares, seguindo o pensador russo, seria um riso de autoafirmação do sujeito.

Embora a divisão social durante o medievo, questão perceptível na pesquisa de Bakhtin (2013), seja uma interpretação contestada por uma série de intelectuais, por exemplo, Hilário Franco Júnior (1996) defende que a delimitação é algo complexo para se pensar o conjunto social nesse contexto envolvendo a Idade Média e o Renascimento, em virtude da transitoriedade das pessoas por meio de diferentes vertentes sociais, seja do espaço "popular" ou "erudito", dificultando assim, a conceituação acerca da camada de pertencimento dos sujeitos. Tendo feito a ressalva sobre as vertentes de interpretação, é importante reconhecer uma característica peculiar dos "populares" quando se relacionavam com o riso em seus meios.

Atestar a presença do riso na Alta Idade Média equivale a uma perspectiva de ludibriar os poderes oficiais. O trabalho de Bakhtin (2013) caminhando mais nessa perspectiva de observação, influenciou e continua a influenciar um número considerável de pesquisadores. Na ótica de Macedo (2000) a leitura de Bakhtin é obrigatória para aqueles que se interessam pela temática do riso no contexto medieval. A divisão da Idade Média, apresentando camadas distintas, tendo na presença do riso ou na sua ausência, um caráter determinante para as representações socioculturais, possui um longínqua teia de análises e interpretações, tanto dentro do núcleo religioso/oficial, quanto fora, incluindo os textos apócrifos.

Para compreender melhor essa última afirmação, é importante entender como algumas teorias pautadas nas leituras bíblicas acerca da criação do mundo, e muito presentes durante o período medieval, com ênfase na sua estruturação enquanto sociedade, não estabeleceram relação com o riso, pelo contrário: "Nos sistemas de valores do cristianismo, este foi dessacralizado e reduzido à categoria de gesto profano" (MACEDO, 2000 p. 53). Por 
exemplo, Deus, em momento algum teria rido ao criar o mundo, porque era um ser perfeito, e somente era possível rir das imperfeições, algo não condizente com os desígnios de Deus.

Ao criar o mundo, Deus teria feito tudo em perfeita harmonia, valorizando o belo e o sublime. Se o riso se manifesta pela imperfeição, de acordo com a teologia clássica, como rir em um local que a imperfeição não existe? É possível acompanhar melhor à discussão, tendo como parâmetro as atribuições defendidas por Minois: “O Jeová bíblico é, certamente, um tanto inquieto. "No início, Deus criou o céu e a terra", diz a Bíblia. Por amor ou por tédio? Essa criação não tem nada de engraçado, e apenas os textos gnósticos imaginaram um riso divino quando da criação" (2003, p. 112). Na teologia clássica, o riso teve seu lugar relegado. No entanto, dentro desse contexto de estruturação da Alta Idade Média é possível identificar a influência teórica de pensadores da Filosofia, como Aristóteles e Platão.

Aristóteles ao dissertar sobre o riso, apresenta-o como elemento eminentemente humano, afirmando que o homem é o único animal que ri. A afirmação ressoou na Idade Média, trazendo consigo algumas questões para serem pensadas pelos teóricos defensores da necessidade da ausência do riso: "O riso torna-se a prova por excelência da ambiguidade própria a condição humana: a superioridade em relação ao mundo físico e aos seres irracionais, e a inferioridade em relação ao transcendental e ao eterno" (ALBERTI, 1999, p. 69). O caráter ambíguo do homem e sua relação com o riso, é um aparente problema que se volta para os primeiros seres humanos, de acordo com a ótica cristã, que são Eva e Adão.

Por exemplo, se o riso é um fenômeno humano, como explicar a relação de Adão e Eva com o riso? Esse suposto problema não teve grandes consequências para ser resolvido pela teologia clássica, porque o princípio da perfeição se enquadraria também nas primeiras figuras humanas. Adão e Eva eram seres humanos, no entanto, teriam sido construídos à imagem e semelhança de Deus, e como o ser supremo não riu, em virtude do seu caráter de perfectibilidade, aqueles criados à sua imagem e semelhança seguiram o mesmo caminho. Ademais, de acordo com essa leitura, não havia objeto risível algum capaz de fazer Adão e Eva sorrirem.

Vivendo no jardim do Éden, Adão e Eva se depararam com um espaço de plena harmonia, de abundância, de beleza esplendida em todos os níveis, inclusive neles próprios. Diante desse estado de harmonia, não havia nenhuma perspectiva de transformação, não sentiam vergonha de seus estados naturais, o fato de estarem nus era algo sem importância, olhavam para o lado e percebiam, simplesmente, a plenitude da existência enquanto seres. Sem nenhum defeito no espaço que habitavam, não haveria motivos para o riso. 
Porém, o jardim do Éden não era composto somente de belas flores, porque, repentinamente, surge um ser capaz de desestabilizar essa beleza irradiante, tanto divina, quanto humana. O ser aparece transvestido da serpente falante, mas, sua essência verdadeira é demoníaca, ou melhor, é o próprio Diabo. Com a aparição repentina do Diabo, e todo o enredo narrativo que o envolve, o conceito de perfeição se inverte, e a capa protetora nos olhos de Adão e Eva é despida, e eles passam a ver, refletir e compreender as imperfeições da existência humana. É como se dissessem: "Somos seres humanos, consequentemente, não somos perfeitos":

\begin{abstract}
Agora, pode-se rir. Há de quê: rir do outro, desse fantoche ridículo, nu, que tem um sexo, que peida e arrota, que defeca, que se fere, que cai, que se engana, que se prejudica, que se torna feio, que envelhece e que morre - um ser humano, bolas! uma criatura decaída. O riso vai se insinuar por todas as imperfeições humanas. É uma constatação de decadência e, ao mesmo tempo, um consolo, uma conduta de compensação, para escapar ao desespero e à angústia: rir para não chorar. Eis aí o que os pais da Igreja recriminam: em lugar de chorar sobre nossa decadência, o que seria marca de arrependimento, rimos de nossas fraquezas, e essa é nossa perda. Vemos nosso nada e rimos dele: um riso diabólico (MINOIS, 2003, p. 112-113).
\end{abstract}

De acordo com a interpretação, o conceito de riso surge repentinamente na história cristã ocidental ligado a antítese de Deus. Se não fosse a interferência do Diabo, sua intromissão, inveja, e outros adjetivos pejorativos, o riso não teria aparecido como problema. Assim, o riso não somente seria uma invenção diabólica, como teria passado a ser aperfeiçoado pelos seres humanos, em virtude de inúmeros elementos risíveis que o próprio ser produz, sendo um reflexo das suas imperfeições. Desassociar o riso da esfera demoníaca foi uma tarefa árdua que os ridentes cristãos medievais tiveram que se relacionar.

Procurando associar o riso ao demônio, inúmeras regras monásticas foram escritas, apresentando os malefícios que o riso proporcionava no indivíduo, inclusive, afastando o sujeito ridente dos princípios elementares da doutrina cristã, que valorizava a seriedade e humildade. Tendo o riso como epicentro, é sempre importante ressaltar, a presença do Diabo durante o período medieval, caminha lado a lado com a presença de Deus, quando um não existe sem a presença do outro.

A Alta Idade Média conviveu com a presença do demônio de forma unilateral, no qual, associar o riso ao Diabo não foi uma tarefa das mais árduas, digamos para o clero religioso: "Isto me parece uma observação bastante importante, porque na história verdadeira o riso e a alegria andam lado a lado com o ódio e o medo" (GUREVICH, 2000, p. 86). 
Sagrado e profano, riso e tristeza, elementos apresentados de forma ambivalente pelos teólogos clássicos do cristianismo.

Os tratados escritos pelos doutores da Igreja, assim como alguns textos apócrifos, tiveram um poder de penetração significativo durante o cristianismo nascente, mesmo diante de um público que, na maioria das circunstâncias, não detinha o domínio da leitura. No entanto, a ideia central desses tratados circulava no imaginário coletivo das pessoas, muito em decorrência da oralidade desempenhar um papel sensível no compartilhamento dos valores escritos, como destaca Macedo: "Num mundo cuja comunicação far-se-ía basicamente por via oral, e que o domínio da escrita seria o apanágio de uma minoria de letrados, a compreensão dos códigos de comunicação, focalizados na gestualidade e nas palavras, permaneceria um dado fundamental" (2000, p. 55). É possível ter uma noção dessa crítica austera dos tratados religiosos sobre o riso por meio da análise de Minois:

\begin{abstract}
Ninguém contribuiu mais para demonizar o riso que os pais da Igreja. Tertuliano investe contra as comédias, espetáculos demoníacos e impudicos. Basílio de Cesareia escreve que "não é permitido rir, em qualquer circunstância, por causa da multidão que ofende a Deus, desprezando sua lei. ... O Senhor condenou aqueles que riem nesta vida. Portanto, é evidente que, para os cristãos, não há circunstâncias em que possam rir". Ele se repete na Epístola 22: o cristão "não deveria brincar; ele não deveria rir nem tolerar os que fazem rir", porque o riso vem do prazer carnal, consequência do pecado e, portanto, do diabo. Além do mais, o riso pode nos fazer esquecer o medo constante que devemos ter do inferno (2003, p. 126).
\end{abstract}

A lista de nomes do cristianismo que escreveram, ora condenado o riso, ora indicando modos e maneiras de rir, e sobre o que rir é grande, com importantes nomes para a Igreja de outrora e também para os dias atuais, tais como Santo Agostinho, Santo Ambrósio, São Jerônimo, e tantos outros. Não há um pensamento único entre esses doutos da Igreja acerca do riso, mas, se é possível haver uma confluência, essa desemboca no caráter da desconfiança para com o riso, no sentido de entenderem o fenômeno como pertencente à uma esfera de proximidade diabólica.

Assim, se o riso ameaçasse se manifestar, deveria ser contido rapidamente, porque era uma expressão do corpo, mas não era interpretado como elemento específico do físico, porque o corpo somente manifesta as intenções do espírito. Há uma nítida associação entre corpo/alma nessa forma de interpretação. Desse modo, o indivíduo ridente evidenciava a degeneração do espírito, em virtude do corpo estar possuído pelo demônio. O comportamento era de tal forma observado pela Igreja Católica, que muitas regras monásticas foram construídas para regulamentar as atividades cotidianas, como a Regula Magistri: 
A Regula Magistri fala da "passagem da boca", a "barreira dos dentes" etc. Quando o riso está começando, ele deve, a todo custo, ser impedido de se expressar. Assim vemos como o riso é a pior de todas as formas de expressão do mal que vêm de dentro: a pior poluição da boca. Todas as idéias são amarradas a uma fisiologia cristã bastante extraordinária, por trás da qual podemos detectar tratados médicos, e por assim dizer, crenças fisiológicas (LE GOFF, 2000, p. 73-74).

Definitivamente, a vida do sujeito ligado ao cristianismo, e ao mesmo tempo, sendo um indivíduo brincalhão, não era nada fácil dentro dos primeiros séculos do período medieval, porque tinha que conviver com uma série de dificuldades no campo do imaginário. A primeira delas se encontra na dificuldade para controlar o riso, essência humana, e a segunda, em decorrência da primeira, porque a todo o momento que soltava um riso, segundo os tratados interpretativos sobre a Bíblia, se afastava mais dos preceitos de Deus, e para isso não acontecer, os dentes, como apresenta a citação, desempenhavam um papel, preponderante, de barreira. Mas, não era somente os tratados que desempenhavam esse papel "perturbador" para com o sujeito, em virtude do cristianismo se valer de outros meios para deixar de sobreaviso o ridente. Nesse âmbito, a representação designada a Jesus Cristo, e sua relação com o riso, vão desempenhar um papel preponderante.

\section{Representação: Jesus Cristo e o Riso}

Uma das grandes justificativas para uma observação do catolicismo para com o riso esteve ancorado na interpretação/representação atribuída a Jesus: "Em geral, os redatores dos textos destinados a servir de modelo para a vida claustral preocuparam-se com a questão da admissibilidade do riso na conduta dos monges e, de um modo geral, partiram dos mosteiros as restrições mais severas em relação ao referido gesto (MACEDO, 2000, p. 59-60). De acordo com as leituras oficiais, "o filho de Deus" não teria rido durante a sua passagem pela Terra. A afirmação surgiu somente no final do século IV por meio da teoria levantada por João Crisóstomo, e logo teve uma considerável capacidade de penetração no seio medieval, influenciando escritores ligados à história da Igreja no decorrer dos séculos seguintes.

A austeridade de João Crisóstomo para com o riso esteve associada ao seu contexto de vivência, quando, no início do século $\mathrm{V}$, os valores de sustentação do Império Romano, passando pelos hábitos sociais, econômicos, culturais, e também no tocante a religião se mostravam cada vez mais fragmentados e discutidos no conjunto da sociedade. Diante desse contexto de efervescência e iminente queda do projeto político de sustentação do 
cristianismo, o Bispo de Constantinopla não teve dúvidas em associar aos fatores de desestabilidade social os costumes dos seus contemporâneos. Nessa esfera, o riso apareceu como um dos indícios representativos da degeneração do ser humano.

\begin{abstract}
Nestes novos comportamentos mediadores entre o homem e o Deus cristão, a busca da interiorização far-se-ia pelo controle da palavra e do gesto, pela educação do corpo, negação dos apetites carnais, contenção dos impulsos desordenados, enfim, pelo autocontrole físico e espiritual (MACEDO, 1997, p. 101).
\end{abstract}

Já no Novo Testamento, o riso é apresentado como sinônimo de zombaria, como algo ímpio, condenado e deplorável para os bons cristãos. Para os seguidores de Cristo, os exemplos terrenos do "mestre" seriam suficientes para se espelharem e procurarem conduzir suas vidas de acordo com os seus ensinamentos. Nesse aspecto, ressaltar a teoria de como Jesus teria se relacionado com o riso era um mecanismo de fundamental importância para o cristianismo nascente, no tocante a reforçar as suas ideias acerca da demonização desse fenômeno.

Por exemplo, em sua vida terrena, Jesus teria passado por inúmeras provações, e diante das dificuldades encontradas, seus adversários partiram para a zombaria, com dizeres como "salve-se rei dos judeus", em tom irônico. O filho de Deus teria sido objeto do riso, de gracejos zombeteiros:

O tom é nitidamente mais grave no Novo Testamento. Mesmo que o mito de que
"Jesus nunca riu" só se tenha desenvolvido no fim do século IV, com João
Crisóstomo, é preciso admitir que os Evangelhos, os Atos e as Epístolas são muito
severos em relação ao riso. Não fazem nenhuma menção de riso em Cristo. Ao
contrário, são os adversários que riem: eles zombam dele quando ele afirma que a
filha de um notável não está morta, mas dorme; o próprio Jesus anuncia que
escarnecerão dele; ele é ridicularizado pelos soldados por ocasião da Paixão: 'Salve,
rei dos judeus"”. As beatitudes condenam claramente o riso neste mundo: "Felizes
vós que chorais agora: vós rireis. ... Infelizes vós que ris agora: ficareis em luto e
chorareis" (MINOIS, 2003, p. 120).

Quando apresenta a ideia dos adversários de Cristo, afeitos ao riso, há uma nítida associação do riso ao elemento diabólico, porque adversário de Cristo, é, automaticamente, inimigo de Deus, e o inimigo atende pelo nome de Diabo. Jesus, segundo os relatos bíblicos, foi tentado pelo Diabo algumas vezes, como na passagem mais emblemática, quando é levado ao deserto pelo demônio e passa por algumas provações, ou provocações. Entre uma dessas, o Diabo diz: "Se tu, pois, fizeres um ato de adoração diante de mim, tudo será teu" (LUCAS, 4, 
7). Esse ato de adoração poderia ter sido caracterizado por um riso? Diante da linha de raciocínio construída até então, possivelmente sim. Porém, na continuidade do enredo bíblico, é possível ver a serenidade de Jesus, porque em nenhum momento ele entra no tom jocoso das brincadeiras do Diabo.

É possível acompanhar melhor o raciocínio por meio das análises construídas por Verena Alberti: "O riso era em geral condenado nos textos teológicos porque não haveria na Bíblia nenhum indício de que Jesus Cristo rira algum dia, apesar de dispor da risibilitas, assim como de todas as nossas fraquezas (1999, p. 68). Jesus tinha as suas fraquezas, em virtude de ser também humano, e como consequência, poderia ter tendência para o pecado, e como rir, de acordo com as interpretações, seria um pecado, a eminência do riso sempre esteve próxima dele. Mas, mesmo o riso estando do seu lado, Jesus teria sido irredutível, porque o seu desejo de não pecar teria sido mais forte do que suas fraquezas humanas.

Diante desse espaço caracterizado pelas tentativas de se estabelecer novos comportamentos de conduta social, ter o controle sobre o corpo era uma mecanismo importante para o "verdadeiro cristão". Por meio dessa leitura, se valer de exemplos dentro da própria liturgia sagrada era um procedimento sine quo non, no qual, a Igreja Católica soube utilizar de forma satisfatória para atender aos seus propósitos. Nesse âmbito, não havia figura mais expressiva do que Jesus Cristo, tido e compreendido como elemento essencial de comparação e representação das condutas a serem adotadas pelos seres.

Quem não segue os seus ensinamentos, bom cristão não seria, e não sendo bom cristão, só poderia ser um pagão/herege. Ao identificar o riso como elemento além das suas "fronteiras", a Igreja passou a ter um poder tanto simbólico, por meio de alguns textos bíblicos, quanto prático, exemplo de Jesus, identificando no outro, no não cristão, o poder devastador que o riso poderia exercer, não levando esse indivíduo para a salvação. A leitura de construção una, em torno de si, é uma característica de construção do cristianismo que se manifestou intensamente nos primeiros séculos da Idade Média.

A ideia do eu esteve relacionada com aqueles que tanto teoricamente quanto nas ações cotidianas seguissem às diretrizes cristãs. Porém, o conceito do outro esteve vinculado aos sujeitos que se encontravam envoltos em outras formas de crença, e com isso, evidentemente, não aceitavam com naturalidade as determinações do cristianismo. Ao associar o riso como elemento mais pagão que humano, e por não ter conseguido associa-lo ao controle da sua "cultura", a Igreja demonizava as práticas culturais, sejam elas coletivas, ou mesmo individuais, que se distanciavam das diretrizes dos seus ensinamentos. 
Para o homem medieval, que levasse em consideração os preceitos bíblicos, e, consequentemente, a imagem representativa sobre Jesus Cristo, o riso em seu cotidiano seria, no mínimo, inglório, porque rir afastava-o consideravelmente de Deus, aproximando-o das chamas do inferno. Em um contexto em que o medo caminha lado a lado das práticas do sujeito, é possível presumir que a ideia representativa sobre Jesus teve um impacto de grande envergadura, quando não reprimindo, fazendo com que os ridentes se martirizassem depois de um riso solto. Uma das formas de expressão do medo continua a se manifestar por meio do campo imaginário. E no imaginário do homem medieval, o inferno era um elemento sempre presente.

Assim, no primeiro momento de instalação do cristianismo, rir, como percebemos na primeira parte desse artigo, era uma afronta, tanto para o núcleo oficial, quanto para o imaginário do sujeito, atordoado com a ideia da não salvação: "Daí o surgimento do famoso mito do qual se tirarão consequências mortais para os cristãos: já que não se fala que Jesus riu, é porque ele não riu, e como os cristãos devem imitá-lo em tudo, não devem rir" (MINOIS, 2003, p. 121). Mais do que uma constatação, há um ordenamento social nessa representação sobre Jesus. É possível imaginar o desespero da sociedade, porque o riso é próprio do homem. No entanto, se esse mesmo homem segue a sua natureza humana, estaria se colocando contrário aos exemplos práticos do filho de Deus.

As brincadeiras em torno do cristianismo eram logo reprimidas, provavelmente, como mencionado, pelo caráter zombeteiro a que teria sido submetido Jesus: "Tem-se a impressão de que, por muito tempo, o cristianismo bloqueou esse aspecto zombeteiro do riso, definido como sendo especificamente mau" (LE GOFF, 2000, p. 77). O riso, sendo interpretado como uma expressão da zombaria, direcionado a alguém que sofre, como teria sido a situação terrena de Jesus, não poderia agradar de forma alguma a Deus, pelo fato, de acordo com a leitura teológica, Deus se padecer com o sofrimento dos seus filhos.

Por último, nem todas as manifestações humanas teriam se manifestado em Jesus, enquanto ser humano. Além do riso, é possível perceber o imbróglio que ainda ocasiona algumas das leituras que apresentam as possíveis manifestações de cunho sexual envolvendo Jesus e Maria Madalena. A imagem de Jesus, como ser humano, de carne e osso, era apregoada, ensinada e arraigada na mente dos fiéis, porém, desde que fossem observadas algumas ressalvas. Desse modo, não necessariamente tudo que é próprio do homem, segundo os princípios episcopais, teria sido praticado por Jesus, e seria de bom grado, visando a salvação, que os cristãos se lembrassem desses ensinamentos. 
A imagem de um Jesus sério e não ridente circulou com intensidade durante alguns séculos durante a Idade Média, precisamente entre os séculos IV e X, como apresentado até o presente momento, servindo de construção para um modelo de sociedade idealizada pelas referencias teóricas do cristianismo. Porém, gradativamente, as interpretações sobre o riso foram sendo suavizadas e incorporadas no cotidiano social dos mosteiros, repercutindo com intensidade nas convivências dos sujeitos que se encontravam fora dos espaços clericais, diminuindo à "angústia" do ridente cristão.

Mesmo com a austeridade mais excessiva, se valendo de algumas representações, a Igreja Católica não conseguiu impedir o riso de se manifestar. As pessoas continuaram rindo, inclusive nos locais onde e quando o riso era mais vigiado e perseguido, como era a situação dos mosteiros. Por meio dessa evidência, uma problemática parece ser inevitável para ser pensada no tópico seguinte, a saber: a presença do riso mesmo diante de todas as circunstâncias, pode ser considerada uma vitória humana, em torno das questões atribuídas como sobrenaturais? Ou seja, há a compreensão de que o riso é um fenômeno humano e não diabólico por parte do cristianismo? Enfim, é possível ter melhores condições de levantar hipóteses para responder as problemáticas na discussão que se segue.

\section{O Riso de "Vitória" do Cristianismo}

Pesquisar, ler, refletir, e por último escrever sobre o riso não é uma tarefa das mais fáceis, porque o fenômeno sociocultural se mostra inquieto, independentemente do contexto social que se esteja analisando. A inquietação é um reflexo do caráter sociocultural do fenômeno em si. Por exemplo, procuramos pensar o riso como uma manifestação não afeita, ou aceita pelo cristianismo medieval, com ênfase para a Alta Idade Média, período mais turbulento para o fenômeno. No entanto, mesmo dentro desse contexto, o riso encontrou meios para se entremear, quando a "intromissão" fez com que fosse, gradativamente, incorporado e aceito pela oficialidade da Igreja Católica, invertendo a representação demoníaca atribuída, e passando a representar o riso como a expressão da vitória de Deus sobre o Diabo.

Para que a representação em torno do riso se invertesse, passando de leitura demoníaca para vitória de Deus, foi necessário um longo transcorrer dentro do processo

histórico. É possível elencar alguns exemplos, a Igreja se valeu de métodos para regulamentar o riso, como as regras monásticas, porém, a quantidade de regulamentações foi em virtude das restrições clericais terem encontrado inúmeras resistências no cotidiano das pessoas. Outro 
fator determinante é a compreensão de que não se fala de um riso único dentro da Idade Média, independentemente do período em que se esteja analisando. Assim, o fenômeno é conceituado por diferentes tipos de riso, configurando tipos tolerados pelo catolicismo oficial, e manifestações de riso condenáveis. A assertiva evidencia a não homogeneidade no seio cristão:

\begin{abstract}
Algumas correntes cristãs, sobretudo aquelas ligadas ao paradigma monacal de orientação beneditina, condenaram o riso, enquanto outras, oriundas das correntes mendicantes do monasticismo desenvolvidas no século XIII, não apenas mostraramse favoráveis ao riso, como se esforçaram no sentido de transformá-lo em instrumento pedagógico na transmissão do conteúdo doutrinal junto aos iletrados (MACEDO, 2000, p. 27).
\end{abstract}

Como evidenciado, houve uma nítida transformação em curso no tocante à leitura do riso por parte da Igreja Católica dentro da própria Idade Média, que teve a tendência de humanizar o fenômeno de forma mais intensa a partir do século XII, representado pelo viés de instrumento pedagógico, entendo-o como mecanismo lúdico para a transmissão dos seus valores. Pensando no âmbito oficial, as Universidades cristãs, a partir do mencionado contexto, tiveram um papel importante nesse caráter de humanizar o riso, conseguindo, suavemente, penetrar nas formas mais ortodoxas de se ler e interpretar o mundo.

A influência de Aristóteles $^{2}$ foi fundamental para lideranças religiosas suavizarem e difundirem a ideia de que o riso se tratava de uma manifestação humana: "Esta mudança de atitude em face do conhecimento pode ser observada na revalorização dos aspectos profanos ou naturais da vida humana, assim como na forma de explicar a essência divina a partir de princípios elaborados com base na especulação filosófica" (MACEDO, 2000, p. 65). Por meio de outras influências teóricas, o núcleo cristão compreende que os elementos considerados profanos não necessariamente poderiam ser ruins, havia aspectos positivos também.

A evidência de outras leituras sobre a sociedade e suas manifestações não deve surpreender, porque se trata de mil anos, e pela sua longevidade, não somente o riso, mas vários outros fenômenos socioculturais ocorreram e passaram por diferentes interpretações dentro do mundo medieval: "Finalmente, a tolerância para com o riso e o risível varia em função do grupo de pessoas: o riso e as atividades cômicas são mais tolerados entre os cristãos

\footnotetext{
${ }^{2}$ Sobre a presença de Aristóteles nos séculos finais da Idade Média, a produção literária de Umberto Eco (2014) no seu clássico livro $O$ Nome da Rosa, demonstra ser uma leitura indispensável para se compreender as diferentes formas de tratamento com o fenômeno, quando apresenta a penetração do riso e da filosofia, assim como a rigidez de alguns clérigos, como o personagem Jorge de Burgos, que entendia no riso uma expressão demoníaca.
} 
leigos, menos tolerados entre os sacerdotes e menos ainda no caso dos monges" (ALBERTI, 1999, p. 72). A citação demonstra que não se fala apenas de uma Igreja Católica no contexto medieval, porque esse núcleo é composto por camadas, e por isso as leituras nem sempre se convergiam.

Mas, até no grupo dos monges, teoricamente mais resistentes para com o riso, é possível perceber a presença do fenômeno se manifestando: "Havia um risus monasticus, que era um riso ilegítimo e proibido, mas, ao mesmo tempo, nossos bons monges certamente tiveram momentos de diversão nos mosteiros" (LE GOFF, 2000, p.77). Até mesmo piadas eram escritas pelos monges visando a diversão, desde que não infringissem os ensinamentos divinos, porque "com Deus não se brinca". A demonização teve um efeito devastador, não resta dúvidas, mas, o seu efeito pode ser considerado de curta duração, porque, gradativamente, outras formas de se ler o fenômeno foram sendo introduzidas, evidenciando a permanência resistente do riso:

\begin{abstract}
Nas formas e no próprio culto religioso herdados da Antiguidade, penetrados pela influência do Oriente, e influenciados em parte por certos ritos pagãos locais (sobretudo os da fecundidade), observam-se embriões de alegria e de riso às vezes dissimulados na liturgia, no rito dos funerais, do batismo ou do casamento, ou mesmo em várias outras cerimônias (BAKHTIN, 2013, p. 64).
\end{abstract}

Por mais que houvesse represálias consistentes, como aconteceu no final do século IV e seguintes, de alguma forma, mesmo que dissimulado, o riso se fez presente. $\mathrm{E}$ foi justamente nessas, ou por meio dessas "lacunas" dentro da Igreja Católica, que o riso foi encontrando cada vez mais mecanismos para a sua inserção social, como destaca Minois: “O período é extremamente confuso, e essa confusão, de certa forma, é propícia ao riso, que conhece um início de mutação" (2003, p. 138). Porém, a aceitação cristã para como o fenômeno cultural, que teve o seu balão de ensaio a partir do século VI e VII, não pode ser compreendida como uma mudança de observação específica da Igreja Católica, mas, sendo um reflexo de uma resistência sociocultural de diferentes grupos que se opuseram as normas monásticas mais austeras, e por meio dessa resistência, continuaram rindo.

As denominadas festas pagãs foram essenciais para manterem o riso ativo dentro do contexto medieval, com direito aos divertimentos, mascaradas, danças, muita comida e bebida, entre outros. Diante da impossibilidade de extirpa-las do seu meio, a Igreja recorre ao óbvio, a saber, a ideia da incorporação, no qual o Carnaval representa muito bem o sincretismo das várias manifestações alegres/pagãs com a "aceitação crista": "As festividades 
apontadas, enraizadas nas tradições ancestrais das populações europeias, resistiram ao processo de cristianização, sendo absorvidas pela via do sincretismo" (MACEDO, 2000, p. 231).

Bakhtin, como salientado no início desse artigo, apresenta uma certa divisão de comportamento social dentro da Idade Média, percebendo as camadas populares, imbuídas de manifestações e costumes pagãos, como "rebeldes" às normas vigentes do catolicismo oficial: "Ela opunha-se à imobilidade conservadora, à sua "atemporalidade", à imutabilidade do regime e das concepções estabelecidas, punha ênfase na alternância e na renovação, inclusive no plano social e histórico" (2013, p. 70). Diante dessa, digamos, "rebeldia", as condutas da Igreja direcionadas ao riso, não eram aceitas de bom grado pelos grupos populares, que procuraram, de alguma forma, encontrar mecanismos para ludibriar os poderes vigentes. Se constitui como algo importante compreender melhor os sujeitos que participavam mais ativamente dos folguedos populares, e que direta ou indiretamente, pertenciam ao conjunto popular:

Os clérigos de baixa e média condição, os escolares, os estudantes, os membros das corporações e finalmente os diversos e numerosos elementos instáveis, situados fora dos estratos sociais, eram os que participavam mais ativamente nas festas populares. No entanto, a cultura cômica da Idade Média pertencia de fato ao conjunto do povo. A verdade do riso englobava e arrastava a todos, de tal maneira que ninguém podia resistir-lhe (BAKHTIN, 2013, p. 71).

É perceptível, os principais atores da cultura cômica medieval pertenciam aos núcleos menos privilegiados dentro da hierarquia social do medievo. Nessa última camada, embora o autor dê uma definição genérica acerca do povo, não inserindo, por exemplo, o núcleo dos camponeses, é possível presumir que as pessoas oriundas do campo participavam ativamente dos divertimentos populares, pelo fato de pertencerem aos grupos dos não privilegiados, e por fim, por uma certa distância do catolicismo oficial dos espaços rurais, possibilitando a maior permanência das religiões e manifestações culturais pagãs.

No seio popular, o riso não somente era bem-vindo, como fazia parte da essência dos sujeitos, sem o qual não poderiam existir, porque no riso encontravam um mecanismo de refúgio para suportarem a difícil consciência das suas existências, como defende Hilário Franco Júnior: “Tanto em um caso quanto em outro, o riso era para a sociedade medieval como é para nossa própria sociedade - "um bom remédio contra a opressão e um veículo de expressão da liberdade"” (2000, p. 14). O riso seria um refúgio para o prazer, indubitavelmente, mas não somente isso, sendo um refúgio para à existência humana das 
camadas populares, que percebiam nos folguedos um não lugar, se comparado ao restante do ano, quando se encontravam subjugados pelos privilégios das elites dominantes.

A última afirmação de Bakhtin, sobre a impossibilidade de se resistir ao riso, é um alento para se pensar o entremear do fenômeno sociocultural em todas as esferas do medievo, com destaque para a reestruturação da Igreja a partir do século XII. Algumas hipóteses são levantadas para se compreender esse riso alargado, porque parece que todos riem. A sociedade ri do seu próprio destino, ri da incapacidade de desestabilizar os poderes oficiais, ri da sua própria tragédia, ri da aceitação das normas vigentes, e diante do riso unânime/social, a Igreja ri confortavelmente. Para Minois, o riso amplo representa a configuração de uma sociedade parodística na Idade Média:

\footnotetext{
O homem medieval imita, copia desformando: festa dos loucos, festa do asno, Carnaval, rei da fava, farsas, sermões burlescos, bobos da corte, romances burgueses são outras tantas paródias de clérigos, dos grandes, dos reis, dos nobres, dos comerciantes, mas também dos defeitos e dos vícios. Os grupos brincam de zombar uns dos outros, mas essas zombarias não são contestação: são jogo, jogo que aceita os valores e as hierarquias; que as reforça invertendo-as ritualmente (2003, p. 156).
}

O riso, como uma forma de jogo, inverte a lógica, quando o sujeito parece estar rindo aceitando as normas vigentes, mas, como é um jogo, a aparência fica somente nesse campo. Do outro lado, o riso da Igreja se configura muito mais como um riso de reciprocidade dos diferentes valores culturais, a exemplo, sagrado/profano, do que propriamente um riso de triunfo meramente religioso: "Neste complexo quadro de apropriações e amálgamas o próprio cristianismo incorporou, por vezes, tradições aos quais seus promotores desejaram extirpar, e, entre elas algumas relacionadas com o riso ritual (MACEDO, 1997, p. 109). A própria Igreja parece ter compreendido a dificuldade que teria ao tentar coibir o riso da sociedade, teoricamente sobre o seu controle.

A existência das regulamentações religiosas em torno do riso, e não foram poucas, evidencia o triunfalismo do próprio riso, porque se não houvesse esse triunfo, não haveria motivos para a quantidade excessiva de regulamentações. Por fim, somente se regulamenta o existente: "A cólera, mesmo a divina, nada pode contra o riso, símbolo consagrado da liberdade" (MINOIS, 2003, p. 131). Reconhecer a incapacidade de controlar e restringir o riso por parte do catolicismo representa não somente uma dificuldade da Igreja, tampouco uma vitória literal do Diabo, mas, uma autoafirmação da condição humana, já que o homem é o único animal que ri, como defende Aristóteles, e o único que faz rir, como acrescenta Bergson (1993). 
Entre as formas de resistência e incorporação do riso por parte do catolicismo oficial, é possível destacar o risus paschalis, representando uma missa ao contrário, no qual, os fiéis se viam obrigados a rir perante os gracejos de sujeitos, imitando por meio dos seus gestos e das falas cômicas as altas figuras da Igreja Católica. Como sempre, a ideia da inversão está muito presente no riso medievo, o que caracteriza uma sociedade marcada por hierarquias. Em virtudes das circunstâncias em que estava envolto, rir para o homem medieval era significativo, porque:

\begin{abstract}
Para o homem medieval o riso significa uma vitória sobre o medo, não apenas o temor místico e natural, mas igualmente o medo moral, que oprimia e dominava a consciência, o medo que ultrapassava os aspectos sagrados e inseria-se no mundo profano, o medo do poder divino e também humano, dos mandamentos e leis, da morte, do inferno e de tudo o mais que permeava o imaginário da época, libertando o homem não apenas das censuras exteriores, mas também do grande censor interior. O grande porta-voz de todo esse espetáculo era representado nas figuras dos bufões e os bobos, personagens característicos da cultura cômica da Idade Média (NUNES, 2012, p. 45).
\end{abstract}

$\mathrm{O}$ ato de rir configurou uma autoafirmação do sujeito enquanto sujeito, colocando-o como protagonista de suas próprias ações, pelo fato de relegar o imaginário oficial/religioso para o segundo plano, no tocante ao cotidiano. Segundo plano não significa abandono da Igreja, e sim, um preceito de condução da vida, não necessariamente religioso. Diante das assertivas do contexto, o riso por toda a conjuntura que estava envolto, pode ser considerado um dos mais significativos elementos racionais. Entendo, nessa afirmação, também a presença do eu, do sujeito, do humano, em detrimento das diretrizes idealizadas na totalidade por outrem, a saber, pelo catolicismo austero/oficial/sobrenatural.

Como não teve êxito em seus propósitos iniciais, a Igreja procurou adaptar o riso às suas condições socioculturais, dando-lhe nova roupagem, como as festas populares, passando a ser novamente incorporadas e aceitas no seio cristão, algo que não acontecia desde o século IV. No entanto, o Carnaval, como representação dos folguedos populares, possuía vínculo muito mais próximo das manifestações de variados credos religiosos, do que, propriamente, de caráter cristão, embora tenha sido construído, enquanto manifestação, dentro da Idade Média.

A Igreja entendia essas características, digamos, mais pagãs do que cristãs dos divertimentos populares, porém, diante das inúmeras tentativas inúteis, entendeu a necessidade de aceita-las: “As referidas práticas e crenças foram incorporadas aos sistemas de valores da cristandade, assumindo formas e recebendo significados bem precisos para os 
grupos sociais daquele momento" (MACEDO, 2000, p. 231). Parece ter havido uma compreensão de que era melhor ter o fenômeno próximo, em detrimento dele acontecer distante dos olhares oficiais:

\begin{abstract}
A festa dos loucos é uma das expressões mais claras e mais puras do riso festivo associado à Igreja na Idade Média. Outra dessas manifestações, a "festa do asno", evoca a figura de Maria levando o menino Jesus para o Egito. Mas o centro dessa festa não é Maria nem Jesus (embora se vejam ali uma jovem e um menino), mas o asno e seu "hinham!" Celebravam-se "missas do asno". Possuímos um ofício desse gênero redigido pelo austero eclesiástico Pierre de Corbeil. Cada uma das partes acompanhava-se de um cômico "Hin Ham!". No fìm da cerimônia, o padre, à guisa de bênção, zurrava três vezes e os fiéis, em vez de responderem "amém", zurravam outras três (BAKHTIN, 2013, p. 67).
\end{abstract}

A assimilação do riso foi tamanha, que nos períodos finais da Idade Média, o riso passou por um processo de "metamorfose" ampla dentro do cristianismo, se deslocando da esfera demoníaca/bom/ruim, como evidenciado ao longo do artigo, para um riso literalmente de Deus, ou melhor, um riso “dos filhos de Deus". Rir das desventuras dos demônios passou a ser um dos passatempos prediletos de clérigos. Assim, há uma reviravolta em torno do riso, porque ele teria surgido com o Diabo, e agora se volta contra ele: "Que exemplo de adaptação! Satã trouxe o riso, que é usado contra ele" (MINOIS, 2003, p. 139). Pobre Diabo, vitorioso no início dos tempos, e agora sofrendo as agruras do cristianismo. Ele que sempre zombou dos cristãos, inclusive de Jesus, agora é zombado pelos "filhos de Deus". Diante da constatação da "vitória", os padres riem confortavelmente. E Jesus, será que ri também?

Há uma nítida inversão da leitura sobre o riso, quando, na circunstância que envolvia Jesus, o riso teria sido utilizado para ridiculariza-lo perante os outros homens. Esse tipo específico de riso foi compreendido pelo núcleo religioso mais importante da Igreja Católica como pertencente a uma esfera da maldade demoníaca, porque apresentava o triunfo do Diabo sobre o filho de Deus. Porém, quando se ri das derrotas dos demônios, inverte-se a lógica do riso, porque passa a ser compreendido como um riso de felicidade diante dos êxitos, um riso bom, não somente aceito, mas desejável por e para todo o cristão.

O riso dentro da Idade Média passou por uma série de nuances, quando as diferenças representam a trajetória sociocultural do próprio contexto, marcado por uma austeridade intensa do catolicismo nos primeiros séculos, e ao mesmo tempo, uma resistência dos diferentes valores culturais pertencentes às inúmeras comunidades tidas e compreendidas como pagãs. $\mathrm{O}$ fato do riso não ter sido extinto, no sentido figurativo do termo, representa a sua capacidade para resistir, não somente nas comunidades pagãs, mas do homem, enquanto 
humano. A constatação da incorporação do riso apresenta uma inegável conquista. No entanto, não é o êxito de Deus sobre o Diabo, é uma vitória sistemática do riso, e todas as implicações que a afirmação acarreta.

\section{Considerações Finais}

Estudar qualquer aspecto cultural da Idade Média é, sem dúvida, um desafio importante, porque possibilita perceber as formas de comportamento, tanto do núcleo religioso, como das pessoas que estão, de alguma forma, "subjugados" a esse núcleo, e constatar que, por mais que fosse influente, atuando no campo imaginário das pessoas, a Igreja Católica exerceu um domínio relativo, em decorrência de ter encontrado uma série de barreiras. Diante das dificuldades, em algum momento teve que se adaptar a muitos valores socioculturais provenientes de outras culturas, e entre os valores, o riso desempenhou uma função essencial.

$\mathrm{O}$ riso demonstra ser um dos objetos de estudo capazes de possibilitar o denominado desnudar social da Idade Média. Se o contexto em si passa por diferentes transformações, o riso, compreendido como fenômeno cultural, também acompanha essas modificações. Não há um único riso dentro do período, pelo contrário, há diferentes tipos, que cumpriram um papel de autoafirmação dos sujeitos diante dos ordenamentos religiosos e sobrenaturais.

Procuramos evidenciar ao longo da construção do texto os impactos das regulamentações clericais para com o fenômeno, com ênfase para o início da Idade Média, quando João Crisóstomo exerceu grande influência, levantando a tese de que Jesus nunca havia sorrido enquanto esteve na forma humana, pelo contrário, o riso teria sido utilizado para ridiculariza-lo. Assim, a tristeza, o choro, a penitência e outras manifestações similares, seria muito mais bem quistas aos olhos de Deus, do que o indivíduo sorridente.

Se valer da ideia do riso como manifestação do Diabo foi uma estratégia do cristianismo nascente, podendo ser conferida em passagens de alguns textos bíblicos, tanto oficiais, quanto de textos apócrifos. As construções de associação riso/Diabo não foram poucas, mas, mesmo assim, a sociedade medieval continuou sorrindo. Diante da constatação da ineficiência das regulamentações, o riso foi sendo suavizado no transcorrer dos séculos e, de forma gradativa, incorporado pela Igreja Católica a partir do século XII.

A incorporação representa o sincretismo das manifestações culturais aceitas, ou melhor, "resistentes" ao cristianismo, porque, na sua essência, as manifestações possuíam 
características muito mais populares do que oficiais. Constatar a presença e incorporação do riso pela Igreja Católica no final da Idade Média, pode ser representada por meio de uma vitória humana, já que o riso, parafraseando e tomando a liberdade de acrescentar a definição de Aristóteles, é um fenômeno humano.

\section{REFERÊNCIAS}

ALBERTI, Verena. O riso e o risível: na história do pensamento. Rio de Janeiro: Jorge Zahar: FGV, 1999.

BAKHTIN, Mikhail. A Cultura Popular na Idade Média e no Renascimento: o contexto de François Rabelais. Tradução de Iara Frateschi Vieira. $8^{a}$ ed. São Paulo: Hucitec, 2013.

BERGSON, Henri. O Riso: ensaio sobre o significado do cómico. Tradução de Guilherme de Castilho. $2^{\text {a }}$ ed. Lisboa: Guimarães Editores, 1993.

ECO, Umberto. O Nome da Rosa. Tradução de Aurora Fornoni Bernardini e Homero Freitas de Andrade. $4^{\mathrm{a}}$ ed. Rio de Janeiro: BestBolso, 2014.

JÚNIOR, Hilário Franco. Prefácio in: MACEDO, José Rivair. Riso, Cultura e Sociedade na Idade Média. Porto Alegre/São Paulo: UFRGS/UNESP, 2000.

JÚNIOR, Hilário Franco. Meu, teu, nosso: reflexões sobre o conceito de cultura intermediária. In: A Eva Barbada. Ensaios de Mitologia Medieval. São Paulo: EDUSP, 1996.

LE GOFF, Jacques. O riso na Idade Média. In: BREMMER, Jan; ROODENBURG, Herman. (Org.) Uma história cultural do humor. Tradução de Cynthia Azevedo e Paulo Soares. Rio de Janeiro: Record, 2000.

MACEDO, José Rivair. Riso, Cultura e Sociedade na Idade Média. Porto Alegre/São Paulo: UFRGS/UNESP, 2000.

MACEDO, José Rivair. Riso Ritual, Cultos Pagãos e Moral Cristã na Alta Idade Média. In. Boletim do CPA, Campinas, nº4, pp. 84-111, jul./dez. 1997.

MINOIS, Georges. História do riso e do escárnio. Tradução de Maria Elena O. Ortiz Assumpção. São Paulo: Editora UNESP, 2003.

NUNES, Daniela. O riso sobre diferentes perspectivas: uma breve análise. In: KUYUMJIAN, Marcia de Melo Martins; MELLO, Maria Thereza Negrão de. (Org.) Cultura cômica e ambiência cotidiana: história cultural, risibilidade e humor. Goiânia: PUC, 2012. 